\title{
Article
}

\section{Introduction to the Special Issue in Honour of Margaret Beetham}

Outen, Gemma and Hobbs, Andrew

Available at http://clok.uclan.ac.uk/36952/

Outen, Gemma and Hobbs, Andrew ORCID: 0000-0001-5943-475X (2021) Introduction to the Special Issue in Honour of Margaret Beetham. Victorian Periodicals Review, 53 (4). pp. 471-478. ISSN 0709-4698

It is advisable to refer to the publisher's version if you intend to cite from the work. https://doi.org/10.1353/vpr.2020.0044

For more information about UCLan's research in this area go to http://www.uclan.ac.uk/researchgroups/ and search for < name of research Group>.

For information about Research generally at UCLan please go to http://www.uclan.ac.uk/research/

All outputs in CLoK are protected by Intellectual Property Rights law, including Copyright law. Copyright, IPR and Moral Rights for the works on this site are retained by the individual authors and/or other copyright owners. Terms and conditions for use of this material are defined in the policies page.

\section{CLoK}

Central Lancashire online Knowledge www.clok.uclan.ac.uk

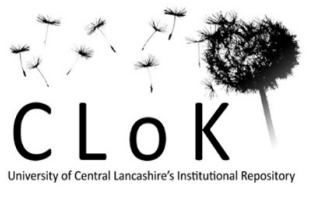




\section{Introduction}

\section{GEMMA OUTEN AND ANDREW HOBBS}

In 2019, Margaret Beetham marked her $80^{\text {th }}$ year with a celebratory research seminar at Manchester Metropolitan University. "Reading Nineteenth-Century Periodicals, with thanks to Margaret Beetham" paid tribute to Margaret's outstanding contribution to feminist and periodical research and her continuing influence on our ways of reading. Papers by Solveig Robinson and Gemma Outen paid homage to Margaret's work by developing her ideas, whilst a postgraduate panel made up of Vic Clarke, Tamara Kaminsky and Catherine Elkin demonstrated her ongoing influence on younger scholars and the longevity of her work. Tributes were also paid by a range of scholars who had worked with and/or been taught by Margaret, and these emphasised her generosity with early career researchers and students alike, her encouragement of collaboration and the ways in which conversations with her always lead to a greater understanding of the complexities of texts. The depth and range of praise pays tribute to Margaret's work but also to her as an individual, and to her nature as collaborative, encouraging, and simply, kind.

Perhaps the highlight of the day though was a paper given by Margaret herself. This reflective paper, entitled “'Situated Knowledges': or the Back Door” thought about her career but also her own home, using the motif of the back door as a literal and metaphorical tool. She considered that she herself had entered through the "back door" of literary studies, questioning canonical texts and drawing on her own interests in the Women's Movement. In a call to arms, she said that she also hoped that female scholars and others entering via the "back door" would pull up a chair, get down a book, read and, as a result, also disrupt ideas of knowledge and notions of scholarship. These ideas are indicative of Margaret's history. She entered academia working in a male-dominated polytechnic focused on science and technology, where Humanities was fighting for space. She became part of a movement challenging the ideology of English Literature as it was taught in universities at the time, introducing texts taught beyond the traditional canon, cross-disciplinary modes of analysis, the use of literary theory to deconstruct traditional assumptions, and the validation of students' life experiences; this movement became widespread enough to earn the distinctive soubriquet "Polytechnic English." 
Brian Maidment, her colleague at Manchester Polytechnic (now known as Manchester Metropolitan University) writes: "It is tempting to heroicise 'Polytechnic English' as a major strand in the development of British academic life in the 1980s-anti-authoritarian, progressive, theoretically self-aware and democratising in its reach. But even ignoring this over-simple generalisation, it is important to acknowledge that it produced ground-breaking scholarly work that re-assessed sources that had previously been undervalued or ignored. It also produced individuals who had the scholarly depth, probity, generosity and persistence to become a role model for a new generation, and Margaret Beetham is one of them."

Margaret, like Brian, found a home in RSVP (which is why the society's journal is the natural place to publish this tribute). Early members of the society such as Sally Mitchell, Rosemary VanArsdel, Martha Vicinus and Eugenia Palmegiano were already challenging the focus on male authors and high-status literary periodicals, providing a supportive intellectual community where Margaret's work on popular women's magazines was recognised and valued. Broader ideas of "author" and "text," influenced by structuralism, legitimised research by Margaret and others on journalists and periodical journalism.

What was particularly new in her approach was her use of theory. Her article "Open and Closed: Periodicals as a Publishing Genre" appeared in the very first "theory" issue of VPR (1989) and continues to be cited today. These very productive ideas of open and closed are developed in three essays here; one by Vic Clarke which combines open/closed with some of Margaret's other preoccupations, times, space and gender, in a meditation on the experience of using digitised periodicals to research the Chartist newspaper the Northern Star; James Mussell uses the part-work Enquire Within to consider how serials regulate their openness with the promise of closure to come, and Julie Codell's essay on Indian nationalist editor Sri Aurobindo Ghose argues that a closed, overdetermined form of periodical was appropriate to resist British imperialism. This application of Margaret's ideas to an Indian journalist is appropriate, given Margaret's recent work, including a memoir about her Indian childhood, which has begun to look at questions of imperialism and whiteness. 
A second major theoretical intervention, "Towards a Theory of the Periodical as a Publishing Genre" (1990), continued many of these original ideas and gave definitions of "a periodical," discussing topics such as heterogeneity, form, and time, and much of this is now seen as foundational "common sense" in our field. She writes about complex ideas and concepts in a clear and concise manner, making them accessible and productive, and ensuring that they are still used, and cited, thirty years after publication.

Margaret's work has also addressed concepts of community and readership, integral to periodical studies and a notoriously difficult area to research. Margaret's thoughtful approach to characterising readers is taken up by Gemma Outen in her essay here, in which she conducts detective work through the Census to contrast the historical readers of a temperance publication with the implied reader in the text. ${ }^{1}$ Further, "Periodicals and the New Media: Women and Imagined Communities" (2006) developed Anderson's seminal idea to apply to periodical studies, but rather, to communities of women, reflecting Margaret's key interest in women readers in the periodical press.

The vast majority of her work is concerned with gender, specifically the role, place and construction of women in the Victorian periodical press. Laurel Brake, Maria DiCenzo and Emma Liggins celebrate her achievement in a round table on her monograph A Magazine of Her Own? (1996), now seen as a foundational text in periodical studies, media history cultural studies and women's history. Her next best known work is perhaps Victorian Women's Magazines: An Anthology (2001), edited with Kay Boardman. This volume built on the work begun in A Magazine of Her Own? and considered differing types of women's magazines, as well as the features within. It created a resource of primary materials, with accompanying analysis and discussion in a work that is an invaluable encyclopaedia of the women's periodical press. Her taxonomies have helped to create a common language, enabling comparisons across time and space, as in the analysis in this issue of a German girls' magazine, Das Kränzchen, by Barbara Korte and Stefanie Lethbridge.

Margaret's interest in women's physical and social experiences, of the complex power relationships of domesticity and desire, is clear in her account of the now notorious "corset correspondence” in “"Natural but Firm': The Corset Correspondence in the Englishwoman's Domestic Magazine" (1991). In this article Margaret explores the debates around corset wearing, and 
principally questions why the corset became such a potent symbol of femininity. In this article, she also considers expected notions of proper and improper femininity, a recurring theme in her work and later taken up in her article "Good Taste and Sweet Ordering; Dining with Mrs Beeton" (2008). Here, Margaret discusses the distinctions of middle-class dining in the Victorian age and the anxieties of the Victorian housewife in maintaining cultural civilisation through the food served in her household. She discusses the middle-class woman as a source of authority in domestic management, a theme again taken up in "Domestic Servants as Poachers of Print: Reading, Authority and Resistance in Late Victorian Britain" (2009). Here, Margaret discusses the experience of the female domestic servant and the role and place of their reading, including the relationship between servant and mistress.

Margaret's work has always been situated and self-aware. Her scholarship comes from her gender, her politics as a feminist and a socialist, and her place in academia, a provincial polytechnic Humanities department. This reflexivity is at the centre of one of her most recent essays, "The Body in the Archive : Reading the Working Woman's Reading" (2017), and some of these ideas are developed by Marianne Van Remoortel and Fien Demarée in their essay on female investigative journalist Lillie Harris, whose literary slumming in the Whitechapel of the Ripper murders raises questions about class, the power of representation and the disembodied digital archive.

Margaret's scholarship has always been attentive to another power relationship, between London and the provinces. Her PhD dissertation used "regionality" - "geographical and political distance from the metropolitan centres of power" - as a category of analysis, alongside class and gender, although this theme was dropped for $A$ Magazine Of Her Own $?^{2}$ One of her first academic publications, a chapter in a 1985 edited collection on class and culture in Victorian Manchester, looked at the city's periodicals, acknowledging London's hegemony, even in locally published magazines. ${ }^{3}$ Margaret is unusual in challenging the metropolitan periodical as the default object of analysis, always explaining why she is studying a London title, rather than taking it for granted. ${ }^{4}$ She returned to regional periodicals later in her career, with articles on Ben Brierley's Journal and summer seaside special editions of Manchester periodicals. As usual, these betray the nuanced understanding of print genres gained only through deep immersion, and a recognition that regional 
publications are sui generis, not weak imitations of London publications. ${ }^{5}$ Whatever the topic, Margaret litters her essays with well-argued apercus applicable to the whole field, such as the greater formal complexity of a periodical in comparison to a novel (useful ammunition when defending the study of periodicals to traditional literary scholars); and she is always on the look-out for new theoretical insights from other fields, using Michel de Certeau and Doreen Massey to analyse seaside specials. As ever, her writing answers those vital questions, "why?" and "so what?"

One way to assess the value of Margaret's scholarship is to see how and where it has been used by other scholars. The work listed in the full bibliography attached to this Introduction has been cited thousands of times, in scores of countries, many outside the English-speaking world, from a deconstruction of the male menopause in Finnish magazines, to representations of women in Chinese advertising. Her ideas have proved fertile in fields far beyond the study of Victorian periodicals - a quick analysis of citations finds them being used in non-historical studies of many types of media beyond magazines, including film, music, photography and the internet; for analysis of gender, fashion and design, in linguistics, psychology, sociology and geography. ${ }^{6}$ She is of course widely cited in studies of Victorian literature, but also of modernism and the middle-brow, and in many historical fields. Citations in undergraduate and school textbooks suggest that her ideas are well established in the academic mainstream. And the relevance of those ideas remains as strong as ever, with, for example, more citations of A Magazine Of Her Own? in the last five years than in any previous five-year period since publication. We are honoured to present this special issue in celebration of Margaret Beetham.

\footnotetext{
${ }^{1}$ Beetham, "In Search of the Historical Reader.” Thanks to Emma Liggins, Brian Maidment, Kathryn Ledbetter, and Laurel Brake for their contributions to this introduction.

${ }^{2}$ Beetham, 'How I Came to Write', 240.

${ }^{3}$ Beetham, “"Healthy Reading”.

${ }^{4}$ Beetham, A Magazine of Her Own?, 7, for example.

${ }^{5}$ Beetham, 'Ben Brierley’s Journal', 75.

${ }^{6}$ Harzing, A.W. (2007) Publish or Perish, available from https://harzing.com/resources/publish-or-perish
} 


\section{$\underline{\text { BIBLIOGRAPHY }}$}

Beetham, Margaret. “'Healthy Reading': The Periodical Press in Late Victorian Manchester.” In City, Class and Culture: Studies of Social Policy and Cultural Production in Victorian Manchester, edited by Alan J. Kidd and Kenneth W Roberts, 167-92. Manchester : Manchester University Press, 1985.

—_. "A Course of our Own: Documents from a Women's Writing Course." LTP, Journal of Literature, Teaching Politics. 4 (1985): 24-38.

_ _ "Between the Polytechnic and the Station or 'Oh! The Difference to Me." Literature and History 13, no. 1 (1987): 95-103.

Beetham, Margaret, Alf Louvre, and Brian E Maidment. “Taking It Seriously: Teaching Popular Culture." In Dialogue and Difference: English into the Nineties, edited by Peter Brooker and Peter Humm, 236-58. London: Routledge, 1989.

Beetham, Margaret. "Open and Closed: The Periodical as a Publishing Genre.” Victorian Periodicals Review 22, no. 3 (1989): 96-100.

_ . "Towards a Theory of the Periodical as a Publishing Genre." In Investigating Victorian Journalism, edited by Laurel Brake, Aled Jones, and Lionel Madden, 19-32. Oxford: Macmillan, 1990.

_ . “Natural but Firm:' The Corset Correspondence in the Englishwoman's Domestic Magazine." Women: A Cultural Review 2, no. 2 (1991): 163-67.

Ballaster, Ros, Margaret Beetham, Elizabeth Frazer, and Sandra Hebron. Women's Worlds: Ideology, Feminity, and the Woman's Magazine. Basingstoke: Macmillan, 1991.

Beetham, Margaret, and Helen Beetham. "The Feminist Reader." Critical Survey 4, no. 2 (1992): $168-73$.

Beetham, Margaret. "Isabella Mayson Beeton.” In Dictionary of National Biography (Supplement). Oxford: Oxford University Press, 1993/2004. 
Beetham, Margaret, Lorna Hughes, and Stuart Lee. Victorian Periodicals Hypertext Project. Oxford: CTI Centre for Textual Studies, Oxford University Computing Services, 1994.

Ballaster, Ros, Margaret Beetham, Elizabeth Fraser, and Sandra Hebron. "A Critical Analysis of Women's Magazines.” In Turning It On: A Reader in Women and Media, edited by Helen Baehr and Ann Gray. London: Hodder Arnold, 1995.

Beetham, Margaret. "Feminism and the End of Eras: Apocalypse and Utopia." In The Endings of Epochs, edited by Laurel Brake, 89-114. London: English Association/Boydell \& Brewer, 1995.

-. A Magazine of Her Own? Domesticity and Desire in the Women's Magazine, 1800-1914.

London: Routledge, 1996.

. 'The Reinvention of the English Domestic Woman: Class and 'Race' in the 1890s Woman's

Magazine." Women's Studies International Forum 21, no. 3 (1998): 223-33.

. "Continuity and Change: The Japanese Woman's Magazine and the Practice of Cultural

History." In Gender and Modernity: Rereading Japanese Women's Magazines, edited by

Ulrike Wohr, Barbara Hamill Sato, and Suzuki Sadami, 167-71. Kyoto: International

Research Center for Japanese Studies, 1998.

- Entries on Isabella Mayson Beeton and Samuel Orchart Beeton. In The Cambridge

Bibliography of English Literature: Volume 4, 1800-1900, edited by Joanne Shattock.

Cambridge: Cambridge University Press. 1999.

. "The Agony Aunt, the Romancing Uncle and the Family of Empire: Defining the Sixpenny

Reading Public in the 1890s." In Nineteenth-Century Media and the Construction of Identities, edited by Laurel Brake, Bill Bell, and David Finkelstein, 253-70. London:

Palgrave Macmillan UK, 2000.

. "In Search of the Historical Reader; The Woman Reader, the Magazine and the Correspondence Column.” SPIEL (Siegener Periodicum Zur Internationalen Empirischen Literaturwissenschaft 19, no. 1 (2000): 89-104. 
Beetham, Margaret and Sophie Levie, eds. Special Issue: "Historical Readers and Historical Reading.” SPIEL (Siegener Periodicum Zur Internationalen Empirischen Literaturwissenschaft 19, no. 1 (2000).

Nelson, Carol, Sakinna Dickinson, Margaret Beetham, and Janet Batsleer. "Border Crossings/Translations: Resources of Hope in Community Work with Women in Greater Manchester." Community, Work \& Family 3, no. 3 (2000): 349-62.

Beetham, Margaret, ed. Special Issue: "The New Woman and the Periodical Press." Media History 7, no. $1(2001)$.

Beetham, Margaret. "Women and the Consumption of Print." In Women and Literature in Britain 1800-1900, edited by Joanne Shattock, 55-77. Cambridge: Cambridge University Press, 2001.

Beetham, Margaret, and Kay Boardman, eds. Victorian Women's Magazines: An Anthology. Manchester: Manchester University Press, 2001.

Beetham, Margaret. "Speaking Together; Heteroglossia, Translation and the (Im)Possibility of the Just Society." Women's Studies International Forum, Women, 25, no. 2 (2002): 175-84.

Heilmann, Ann, and Margaret Beetham, eds. New Woman Hybridities: Femininity, Feminism, and International Consumer Culture, 1880-1930. London: Routledge, 2004.

Beetham, Margaret. “Abel Heywood.” Dictionary of National Biography, Oxford University Press. Oxford. 2004.

. "Ben Brierley's Journal.” Manchester Region History Review 17, no. 2 (2006): 73-83.

. "Periodicals and the New Media: Women and Imagined Communities." Women's Studies International Forum, Feminisms and Print Culture, 1830-1930s, in the Digital Age, 29, no. 3 (1 May 2006): 231-40.

. "Good Taste and Sweet Ordering; Dining with Mrs Beeton." Victorian Literature and Culture 36, no. 2 (2008): 391-406.

. "'Oh! I Do like to Be beside the Seaside!': Lancashire Seaside Publications.” Victorian Periodicals Review 42, no. 1 (2009): 24-36. 
"Domestic Servants as Poachers of Print: Reading, Authority and Resistance in Late Victorian Britain.” In The Politics of Domestic Authority in Britain since 1800, edited by Lucy Delap, Ben Griffin, and Abigail Wills, 185-203. London: Palgrave Macmillan UK, 2009.

Beetham, Margaret. Associate Editor, Dictionary of Nineteenth-Century Journalism in Great Britain and Northern Ireland. General Editors: Laurel Brake and Marysa Demoor. Academia Press and British Library. 2009.

Beetham, Margaret. "Of Recipe Books and Reading in the Nineteenth Century: Mrs Beeton and Her Cultural Consequences.” In The Recipe Reader: Narratives - Contexts - Traditions, edited by Janet Floyd and Laurel Forster, 15-30. Lincoln: UNP, 2010.

_ . “Thinking Back through Our Mother's Magazines: Feminism’s Inheritance from NineteenthCentury Magazines for Mothers.” Nineteenth-Century Gender Studies 6, no. 2 (2010).

Houston, Natalie M, and Margaret Beetham, eds. Special Issue: “Tradition and the New." Victorian Periodicals Review 47, no. 4 (2014).

Beetham, Margaret. "Periodical Writing." In The Cambridge Companion to Victorian Women's Writing, edited by Linda H Peterson, 221-35. Cambridge: Cambridge University Press, 2015. . "Time: Periodicals and the Time of the Now." Victorian Periodicals Review 48, no. 3 (2015): $323-42$.

. "How I Came to Write A Magazine of Her Own?: Domesticity and Desire in the Woman's Magazine, 1800-1914.” Victorian Periodicals Review 50, no. 1 (2017): 238-43.

. "Meeting Mrs Beeton: The Personal Is Political in the Recipe Book." In Food, Drink, and the Written Word in Britain, 1820-1945, edited by Mary Addyman, Laura Wood, and Christopher Yiannitsaros, 187-206. Abingdon: Routledge, 2017.

. "The Body in the Archive : Reading the Working Woman's Reading." In Researching the Nineteenth-Century Periodical Press, edited by Alexis Easley, Andrew King, and John Morton, 145-60. Routledge: London, 2017.

. "Preface: The Role of Gender in Defining the 'Women's Magazine." In Women and the Periodical Press in China's Long Twentieth Century: A Space of Their Own?, edited by 
Michel Hockx, Joan Judge, and Barbara Mittler, xxv-xxx. Cambridge: Cambridge University Press, 2018.

_ .The Rise and Rise of the Domestic Magazine: Femininity at Home in Popular Periodicals." In Women, Periodicals and Print Culture in Britain, 1830s-1900s: The Victorian Period, edited by Alexis Easley, Clare Gill, and Beth Rodgers, 18-. Edinburgh: Edinburgh University Press, 2019.

. Home is Where: The Journeys of a Missionary Child, London. Darton, Longman and Todd. 2019. 